\title{
KORELASI ANTARA KEMAMPUAN PEMAHAMAN KONSEP DAN PENALARAN INDUKTIF SISWA MELALUI PENDEKATAN GENERATIF
}

\section{Yanti Mulyanti ${ }^{1}$}

\begin{abstract}
The ability of students' conceptual understanding and inductive reasoning in mathematics learning needs to be considered, because conceptual understanding can organize and consolidate mathematical thinking, as well as reasoning will gain meaningful knowledge for students. This can be done through learning by using generative approach. This research is a correlational research to know the correlation between the ability of conceptual understanding and inductive reasoning of VII grade students at SMP Negeri 3 Cugenang-Cianjur in 2009/2010 Academic Year on triangle and quadrilateral materials, using generative approach. Based on the results of correlation analysis, it was obtained $r_{x y}=0.618$ in moderate correlation, and it can be concluded that there is a positive correlation between the ability ofstudents' conceptual understanding and inductive reasoning.
\end{abstract}

Keywords: Correlational Study, Conceptual Understanding, Inductive Reasoning, Generative Approach.

ABSTRAK: Kemampuan pemahaman konsep dan penalaran induktif siswa dalam pembelajaran matematika perlu diperhatikan, karena pemahaman konsep dapat mengorganisasi dan mengkonsolidasi berpikir matematika, begitu juga penalaran akan memperoleh pengetahuan yang bermakna bagi siswa. Hal tersebut dapat dilakukan salah satunya melalui pembelajaran menggunakan pendekatan generatif. Penelitian ini merupakan penelitian korelasional untuk mengetahui hubungan antara kemampuan pemahaman konsep dan penalaran induktif matematika siswa kelas VII SMP Negeri 3 Cugenang-Cianjur tahun pelajaran 2009/2010 pada materi segitiga dan segiempat, menggunakan pendekatan generatif. Berdasarkan hasil analisis korelasi, diperoleh $r_{x y}=0,618$ berada pada korelasi sedang, dan dapat disimpulkan bahwa adanya korelasi positif antara kemampuan pemahaman konsep dan penalaran induktif siswa.

Kata Kunci: Studi korelasi, kemampuan pemahaman konsep, kemampuan penalaran induktif, pendekatan generatif.

\section{PENDAHULUAN}

Tujuan pembelajaran matematika yaitu belajar untuk bernalar, memecahkan masalah, mengaitkan ide, dan pembentukan sikap positif terhadap matematika (Sugiyono 2014). Pendidikan matematika pada hakekatnya memiliki dua arah pengembangan yaitu untuk memenuhi kebutuhan masa kini dan masa datang. Untuk kebutuhan masa kini, pembelajaran matematika mengarah kepada pemahaman

1Dosen Pendidikan Matematika, Universitas Muhammadiyah Sukabumi, Email: yanti_khairan@yahoo.co.id 
matematika dan ilmu pengetahuan lainnya. Untuk kebutuhan di masa yang akan datang mempunyai arti lebih luas yaitu memberikan kemampuan nalar yang logis, sistematis, kritis dan cermat serta berpikir objektif dan terbuka yang sangat diperlukan dalam kehidupan sehari-hari serta menghadapi masa depan yang selalu berubah (Susetyo, 2014). Matematika sebagai bagian dari kurikulum sekolah tentunya diarahkan untuk mendukung tercapainya tujuan dan pengembangan tersebut.

Baroody (Dahlan, 2004) mengungkapkan bahwa terdapat beberapa keuntungan apabila siswa diperkenalkan dengan penalaran, karena dapat secara langsung meningkatkan hasil belajar siswa. Keuntungan tersebut adalah jika siswa diberi kesempatan untuk menggunakan keterampilan bernalarnya dalam melakukan pendugaan-pendugaan berdasarkan pengalamannya sendiri, maka siswa akan lebih mudah memahami konsep. Misalnya siswa diberikan permasalahan dengan menggunakan benda-benda nyata, melihat pola, mereformulasikan dugaan tentang pola yang sudah diketahui dan mengevaluasinya, sehingga hasil yang diperoleh lebih informatif. Hal ini akan lebih membantu siswa dalam memahami proses yang telah disiapkan dengan cara doing mathematics dan eksplorasi matematika.

Mengacu pada pandangan konstruktivisme yang memandang bahwa pembelajaran merupakan suatu proses, situasi dan upaya yang dirancang guru, sehingga membuat siswa dapat belajar. Guru harus berperan sebagai fasilitator, motivator dan manager di kelas. Perlunya kemampuan pemahaman konsep dan penalaran induktif siswa dikembangkan dalam pembelajaran matematika, karena sesuai dengan pandangan bahwa matematika adalah produk dan proses. Pemahaman konsep dalam pembelajaran matematika perlu diperhatikan karena melalui pemahaman konsep, siswa dapat mengorganisasi dan mengkonsolidasi berpikir matematikanya, yang akhirnya dapat membawa siswa pada pemahaman yang mendalam tentang konsep matematika yang telah dipelajari. Penalaran perlu mendapatkan perhatian khusus dari guru karena melalui penalaran yang benar akan diperoleh pengetahuan yang bermakna bagi siswa.

Salah satu alternatif yang sesuai yang dapat digunakan yaitu pendekatan generatif. Tahapan-tahapan yang terdapat dalam pendekatan generatif dapat membuat siswa untuk belajar menjadi aktif dalam mengkonstruksikan pengetahuannya. Disamping itu melalui pembelajaran generatif tercipta suatu iklim belajar, siswa mendapatkan kebebasan dalam mengajukan ide-ide, pertanyaanpertanyaan dan masalah-masalah, sehingga belajar matematika lebih efektif dan bermakna (Chairhany, 2008).

Osborn dan Wittrock (Holil, 2008) mengungkapkan bahwa pembelajaran generatif merupakan suatu pendekatan pembelajaran yang melibatkan siswa secara aktif mengkonstruksi pengetahuan baru dengan menggunakan pengetahuan yang sudah dimiliki siswa sebelumnya. Pendekatan generatif berlandaskan pada paham 
konstruktivisme, dengan asumsi dasar bahwa pengetahuan dikonstruksi dalam pikiran siswa, siswa sendiri yang aktif mengkonstruksi dan mengembangkan konsep matematika, sedangkan guru hanya sebagai fasilitator, organisator, dan motivator. Pendekatan pembelajaran generatif mempunyai empat tahapan, yaitu tahap persiapan, tahap menfokuskan, tahap tantangan, dan tahap aplikasi.

\section{METODE PENELITIAN}

Jenis penelitian ini yaitu korelasional untuk mengetahui hubungan antara kemampuan pemahaman konsep dan penalaran induktif pada materi segitiga dan segiempat, menggunakan pendekatan generatif berdasarkan koefisien korelasi. Sampel penelitian yaitu siswa kelas VII SMP Negeri 3 Cugenang-Cianjur tahun pelajaran 2009/2010 sebanyak 70 siswa. Pengumpulan data menggunakan teknik tes, yaitu tes kemampaun pemahaman konsep dan penalaran induktif.

Dilakukan uji prasyarat analisis yaitu uji normalitas untuk mengetahui data terdistribusi normal atau tidak. Pengujian dilanjutkan dengan uji korelasi untuk mengetahui tingkat keterkaitan antara kemampaun pemahaman konsep dan penalaran induktif yaitu menentukan nilai $\alpha$ sebesar 0,05 dengan kriteria uji tolak $\mathrm{H}_{0}$ jika nilai signifikansi $<\alpha$. Statistik uji yang digunakan yaitu statistik uji korelasi product momen Pearson dengan menggunakan SPSS 24,0 for windows.

\section{HASIL DAN PEMBAHASAN}

Terpenuhinya asumsi kenormalan distribusi data merupakan prasyarat uji korelasi. Berikut disajikan hasil uji normalitas kemampuan pemahaman konsep (KPK) dan kemampuan Penalaran Induktif (KPI) seperti pada Tabel 1 berikut.

Tabel 1. Uji Normalitas

\begin{tabular}{lr|r|r|r|r|r}
\hline & \multicolumn{3}{c}{$\begin{array}{c}\text { Kolmogorov- } \\
\text { Smirnova } \\
\end{array}$} & \multicolumn{4}{c}{ Shapiro-Wilk } \\
& Statistic & Df & Sig. & Statistic & df & Sig. \\
\hline KPK & .148 & 35 & .050 & .955 & 35 & .166 \\
\hline KPI & .206 & 35 & .001 & .950 & 35 & .111 \\
\hline & & & & & & \\
\hline
\end{tabular}

Berdasarkan Tabel 1 uji normalitas menggunakan Shapiro-Wilk, diketahui bahwa nilai sig $\mathrm{KPK}=0,166>0,05$, sehingga $\mathrm{H}_{0}$ diterima. Jadi populasi skor 
kemampuan pemahaman konsep matematika siswa berdistribusi normal. Begitu pula skor kemampuan penalaran induktif matematika siswa berdistribusi normal, terlihat dari nilai sign $\mathrm{KPI}=0,111>0,05, \mathrm{H}_{0}$ diterima.

Uji statistik berikutnya yaitu uji korelasi untuk melihat koefisien korelasi yang diperoleh tersebut berbeda secara signifikan dari nol atau tidak, maka dilakukan pengujian hipotesis menggunakan uji $\rho=0$. Maksudnya adalah bila menggunakan hipotesis nol apakah $\mathrm{H}_{0}: \rho=0$ diterima atau ditolak. Perhitungan korelasi antara kemampuan pemahaman konsep dan penalaran induktif siswa seperti pada Tabel 2 berikut.

Tabel 2. Korelasi Antara Kemampuan Pemahaman Konsep dan Penalaran Induktif

\begin{tabular}{rlr|r}
\hline & & KPK & \multicolumn{1}{c}{ KPI } \\
\hline KPK & $\begin{array}{l}\text { Pearson } \\
\text { Correlation }\end{array}$ & 1 & $.618^{* *}$ \\
& Sig. (2-tailed) & & .000 \\
\cline { 2 - 4 } & $\mathrm{N}$ & 35 & 35 \\
\hline KPI & $\begin{array}{l}\text { Pearson } \\
\text { Correlation }\end{array}$ & $.618^{* *}$ & 1 \\
\cline { 2 - 4 } & Sig. (2-tailed) & .000 & \\
\cline { 2 - 4 } & $\mathrm{N}$ & 35 & 35 \\
\hline
\end{tabular}

Berdasarkan Tabel 2 diperoleh koefisien korelasi Pearson antara kemampuan pemahaman konsep dan penalaran induktif siswa sebesar $r_{x y}=0,618$ dan nilai signifikansi (sig.) $=0,000$. Karena nilai signifikansi $=0,000<\alpha=0,05$ maka $\mathrm{H}_{0}$ : $\rho=0$ ditolak. Dengan demikian, korelasi antara kemampuan pemahaman konsep dan penalaran induktif siswa adalah berbeda secara signifikan dari 0 . Menurut Hinkle, dkk. (1988) bahwa mengenai tafsiran koefisien korelasi, $r_{x y}=0,618$ berada pada korelasi sedang. Dari hasil uji korelasi yang dilakukan, dapat disimpulkan bahwa adanya korelasi positif antara kemampuan pemahaman konsep dan penalaran induktif siswa. 


\section{KESIMPULAN}

Kesimpulan dari penelitian ini yaitu terdapat korelasi positif antara kemampuan pemahaman konsep dan penalaran induktif matematika siswa.

\section{DAFTAR PUSTAKA}

Chairhany, S. (2008). Meningkatkan Kemampuan Pemahaman dan Penalaran Logis Matematis Siswa MA Melalui Model Pembelajaran Generatif. Tesis Master Pendidikan PPs-UPI: tidak dipublikasikan.

Dahlan, J. A. (2004). Meningkatkan Kemampuan Penalaran dan Pemahaman Matematika Siswa Sekolah Lanjutan Pertama Melalui Pendekatan Open-Ended. Disertasi Doktor PPS UPI Bandung: tidak dipublikasikan.

Hinkle, D. E., Wiersma, W., \& Jurs, S. G. (1988). Applied statistics for the behavioral sciences. Boston: Houghton Mifflin

Holil, A. (2008). Pembelajaran Generatif (MPG). [Online]. Tersedia: http://anwarholil.blogspot.com/2008/04/pembelajaran-generatif-mpg.html [28 Januari 2009].

Sugiyono. (2014). Metode Penelitian Kombinasi. Bandung: Alfabeta.

Susetyo, B. (2014). Statistika untuk Analisis Data Penelitian. Bandung: Refika Aditama. 